\title{
FED's Impact On The Value Of Dollar Through Interest Rates
}

Guclu Atinc, Louisiana Tech University, USA

Yasmine Ocal Atinc, Grambling State University, USA

Matthew Uwakonye, Grambling State University, USA

\begin{abstract}
In this study we aimed to demonstrate how the actions of FED indirectly impact the value of American dollar. We specifically hypothesized that when FED encourages banks to borrow more from each other by holding the discount rate higher than the federal funds rate then this should have a negative impact on the value of dollar and also subsequent higher spread between federal funds rate and prime rate. We also hypothesized that as this spread gets larger a subsequent depreciation in dollar's value and negative effect on unemployment should be observed. Although we were unable to demonstrate the impact when the spread between the prime rate and federal funds rate is considered, our results show that when FED encourages banks to borrow from each other by holding the discount rate higher than the federal funds rate, the American dollar goes down in value and corresponding larger difference between federal funds rate and prime rate is observed.
\end{abstract}

Keywords: Prime Interest Rate; Federal Funds Rate; Interest Rate Spread

\section{INTRODUCTION}

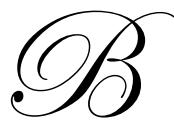

ack in the days when Milton Friedman, the founder of the Monetarist school of thought, argued that when the interest rate is decreased, this would eventually yield to more loans provided to businesses thus increasing their capacity to invest so the aggregate output is increased (Seiler, Shyu, \& Sharma, 1998), he might not have thought about the potential effect of monetary policies on the valuation of currency. In fact, no previous studies have investigated the impact of the spread between Discount Rate and Federal Funds rate and the spread between Federal Funds Rate and the Prime Loan Rate on currency valuation. In this study, we aim to assess the potential effects of FED's activism on value of dollar using historical data from 1971 to 2008. From the streets of Johannesburg to bankrupt financial sector Reykjavik, Iceland and Wall Street district of New York to giant banks of Tokyo, Japan, the value of dollar is a major determinant in world's market mechanisms. FED's policies, as the official agency to determine monetary policies of United States where dollar is the official currency, do have impact on people's perceptions about the value of dollar. Using interest rates, particularly discount rate and its impact on federal funds rate and primary loan rate, as the magic tool, to what extent can FED influence the value of dollar in the world is the main question to be answered in this paper.

\section{HYPOTHESIS DEVELOPMENT}

As an initial step, the proper definition of some of the terms used in this paper may be helpful. Discount rate is determined by Federal Reserve System and approved by its Board of Governors as the interest rate to be charged to commercial banks and other depositary institutions on their borrowing from FED through the discount window (FRB: Monetary Policy, 2009; Miller \& VanHoose, 2004, p:411). In other words, if the banks choose to use FED as the source for their monetary holdings, the cost of that borrowing is determined by the discount rate. Federal funds rate on the other hand, is the rate depository institutions charge other institutions when lending money using their funds in the Federal Reserve System (Cook \& Hahn, 1989). Finally, prime rate, shown to be impacted by federal funds rate (Atesoglu, 2003), is the interest rate banks charges on loans to commercial institutions. The relationship between these three rates have long been investigated by economists (Broaddus \& Cook, 1983; Cook \& 
Hahn, 1988; Atesoglu, 2003) due to the fact that FED's systematic use of discount rate announcements to trigger persistent movements in federal funds rate which in turn likely to have impact on market interest rates (Madura \& Schnusenberg, 1998). In other words, the relationship between these three rates is the mediator for the market activities including the companies' access to funds for investment purposes which happens to one of the three main components of aggregate output (Miller \& VanHoose, 2004).

How might these relationships affect the value of dollar is a question to be answered. In the literature, there is extensive amount of evidence on FED's impact on market conditions. For instance, Ward (1970) observed a significant relationship between discount rate changes and market returns. Thorbecke (1997) found an inverse relationship between announcement of federal funds target and equity returns. There is strong evidence that FED is using discount rate to indirectly affect federal funds rate (Thorton, 1994) so that market mechanisms emerge accordingly. In short, FED's aim is to make sure that the market is moving in the direction FED wants it to move. The value of the currency is certainly a part this process. A significant portion of aggregate output is net exports. Common knowledge says, as the country's currency is devalued, it will be cheaper for others to buy the goods and services produced by the local company which in turn should have a positive effect on net export. On the other hand, the locals will be more reluctant to buy other countries' goods as they become more expensive. The result is either a positive or negative impact on the GDP which is one of the main determinants of a country's wealth. Jensen, Mercer, \& Johnson (1996) mention that impact of various business condition proxies differ among various monetary environments. FED's policies should certainly have some sort of signaling effect on the international players with regard to their perception of dollar. Keynes (1936) discusses how the change in discount rate and federal funds rate will correspond to the actions of the banks. According to this discussion, banks' willingness to loan will be determined primarily by the changes in these two rates. By first hand experience in the current year, we know that how that impacts the whole economy. As the main supplier of dollar, American economy's conditions determine the value of the dollar. In fact, the need for cash in the American market can be considered to be the main factor determining the value of the dollar. We believe that the difference between federal funds rate and discount rate and the discount rate and prime loan rate is somehow related to the valuation of the dollar. Sweeney (2007) analyzed FED's intervention on currency appreciation. He thinks FED's actions have indirect impact on the value of American Dollar. Sourcing from that perspective, we believe the following hypotheses can be formed to explain our logic:

H1: If FED encourages banks to borrow from each other by holding the discount rate higher than federal funds rate, the international market recognizes that as a negative signal so dollar depreciates in value.

One important point to be made here is; we consider FED's actions for holding discount rate to be higher than federal funds rate as inactivism. In other words, when FED is holding on to funds and not giving them away easily, it is harder for banks to provide resources to stimulate the economy. That is why we believe the internal players consider it to be a negative signal for the American economy. Furthermore, the spread between federal funds rate and discount rate is likely to have chain reaction effect on the spread between federal funds rate and prime rate. During these times banks try to increase to this spread in order to increase their profitability (Atesoglu, 2003) so that they get to meet the risk premium of the market. For these reasons, the following hypothesis makes intuitive sense:

H2: If FED encourages banks to borrow from each other by holding the discount rate higher than federal funds rate, the difference between federal funds rate and prime rate also gets larger.

Finally, we have to acknowledge the fact that as the banks charge higher interest rates, the investment activities should go down as proposed by Keynes (1936). Considering the impact of investment on GDP, the dollar's depreciation once again may follow. As the GDP of a country goes down, due to negative investment in this case, the depreceiation in the currency of that country is likely reflect that. Furthermore, the unemployment should also rise as a result of decrease in the amount of investment. Thus the following hypothesis is also proposed:

H3: As the spread between federal funds rate and prime rate gets larger, the value of dollar goes down due to negative signaling effect that spread has on investment activities.

H4: As the spread between federal funds rate and prime rate gets larger, the unemployment should rise due to decrease on investment activities. 


\section{METHODOLOGY}

In this section the data sources are first reported. Following that, the variables used are introduced. The section is concluded by brief information about the statistical method adopted.

\section{Sample}

Two different sources have been used to collect the data. First the three different interest rate information and currency exchange rate information is collected from Federal Reserve Bank Reports. This is a comprehensive database that contains historical information gathered from FED's published reports. To further elaborate the subject, we also collected unemployment data from Federal Reserve Bank St.Louis Database (St.Louis Fed: Employment \& Population, 2009). The original time frame we chose was 1949 to 2009 but due to lack of currency information before 1970; we chose to collect data between January 1971 to December 2008. The final sample came out to be 455 observation points. Further detail about the timing issues is given under variables subsection under this heading.

\section{Variables}

Federal funds rate (FFR): The official monthly federal funds rate as reported in FED's monthly reports is gathered. This is the rate as of the last day of the corresponding month. The first data point is Jan $31^{\text {st }} 1971$ and the last one is Dec $31^{\text {st }} 2008$.

Prime Loan Rate (PLR): The prime rate as of the last day of the corresponding month is collected. The first data point is Jan $31^{\text {st }} 1971$ and the last one is Dec $31^{\text {st }} 2008$.

Discount Rate (DR): The discount rate FED charged historically as of the last day of the corresponding month is gathered. Once again, the first data point is Jan $31^{\text {st }} 1971$ and the last one is Dec $31^{\text {st }} 2008$.

Spread between federal funds rate and the discount rate (DRFFR): This variable is calculated by DR-FFR.

Spread between federal funds rate and prime loan rate (PLRFFR): This variable is calculated PLR-FFR.

SPDummy: This is a binary variable coded as 1 if DRFFR is positive which symbolizes the times where FED is inactive and encouraging banks to borrow from each other rather than using FED's funds and 0 otherwise.

Unemployment Rate (UnRate): The unemployment rate reported as of the beginning of the corresponding month. The reason to look at the value reported at the beginning of the month is to account for FED's actions during the month taking the current unemployment situation into account.

IfURise: This is a binary variable coded as 1 if unemployment has risen comparing to previous month and 0 otherwise. The reason for the creation of this variable was to analyze the potential effects sudden changes in unemployment on FED's policies.

U.S. Dollar-Canadian Dollar exchange rate (USCAN): The official exchange rate reported at the end of the corresponding month is collected. This data is lagged one month to observe the effect of FED's actions on currency rate. For instance, DRFFR and PLRFFR values for 31-Jan-1971 is matched with 28-Feb-1971 currency exchange data. For this reason, the first data point is Feb $28^{\text {th }} 1971$ and the last one is Dec $31^{\text {st }} 2008$ matched with Nov $30^{\text {th }}$ 2008 interest rate data.

U.S. Dollar-British Pound (USUK): Since the Canadian Dollar may move together with American Dollar as Canada being in North America, British Pound is chosen to be the other currency included in this study. Same methodology mentioned for the exchange rate between U.S. dollar and Canadian dollar is also used here. 


\section{Statistical Techniques}

Different techniques were adopted to test the above mentioned hypotheses. First, to test Hypothesis 1, Analysis of Variance (ANOVA) is used to see if exchange rates differed among the times FED was inactive versus active. Second, Logistic Regression is used to test the following model for Hypothesis 2 because the proposed dependent variable is a binary one:

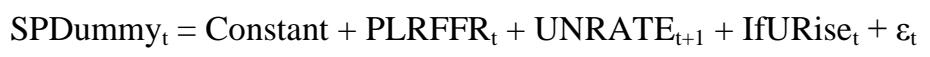

Finally, Time-Series Regression model is used to test Hypotheses 3 and 4. Since autocorrelation is likely to occur in time series model (Durbin-Watson statistic showed that it is), Prais-Winsten transformation is applied to the following model:

PLRFFRt $=$ Constant + USCAN $_{t+1}+$ USUK $_{t+1}+$ UNRATE $_{t+1}+$ IfURise $_{t}+\varepsilon_{t}$

One thing to mention here is that multicollinearity is tested in all models using VIF values. None of the VIF values came out to be over the critical value of 10 .

\section{RESULTS}

Pearson correlations, means and standard deviations of the variables are reported in Table 1. Further, Table 2 includes the ANOVA results for Hypothesis 1. First of all the spread (PLRFFR) difference is statistically significant (at $\mathrm{p}<0.01$ ) between the times it is negative, which symbolizes FED's active role in encouraging banks to borrow money from FED, versus the times it is positive, symbolizes FED's discouragement on banks for using its funds. Furthermore, the currency rates, USCAN and USUK are different among two time periods (at $\mathrm{p}<0.01$ ). ANOVA can only be used to test the null hypothesis of equality of means so we have to look at the mean differences to find support for the hypothesis. In this case the mean exchange rate between U.S. Dollar and Canadian Dollar is 1.13 during positive spread times versus 1.27 negative spread times. The same situation also applies to exchange rate between U.S. Dollar and British Pound ( 0.53 in positive spread times versus 0.53 during negative spread times). Hence, dollar was less valuable during the positive spread times when FED encouraged banks to borrow from each other rather than FED's funds by holding discount rate higher than federal funds rate. This means there is strong support for Hypothesis 1.

Table 1 - Pearson Correlations and Descriptive Statistics

\begin{tabular}{l|c|c|c|c|c|c|c|c|c|c|c}
\hline & Mean & SD & $\mathbf{1}$ & $\mathbf{2}$ & $\mathbf{3}$ & $\mathbf{4}$ & $\mathbf{5}$ & $\mathbf{6}$ & $\mathbf{7}$ & $\mathbf{8}$ & $\mathbf{9}$ \\
\hline 1. FFR & 6.44 & 3.48 & & & & & & & & \\
2. PLR & 8.64 & 3.18 & $0.959^{* *}$ & & & & & & \\
3. DR & 5.93 & 2.69 & $0.958^{* *}$ & $0.945^{* *}$ & & & & & \\
4. DRFFR & -0.51 & 1.19 & $-0.762^{* *}$ & $-0.670^{* *}$ & $-0.545^{* *}$ & & & & \\
5. PLRFFR & 2.19 & 1.01 & $-0.433^{* *}$ & $-0.159^{* *}$ & $-0.331^{* *}$ & $0.521^{* *}$ & & & & & \\
6. USCAN & 1.24 & 0.17 & $-0.214^{* *}$ & -0.067 & $-0.268^{* *}$ & 0.02 & $0.528^{* *}$ & & & & \\
7. USUK & 0.57 & 0.09 & $-0.183^{* *}$ & -0.066 & $-0.207^{* *}$ & 0.068 & $0.427^{* *}$ & $0.730^{* *}$ & & \\
8. UNRATE & 6.15 & 1.38 & $0.316^{* *}$ & $0.312^{* *}$ & $0.387 *$ & -0.050 & $-0.108^{*}$ & $-0.227^{* *}$ & 0.086 & \\
9. SPDUMMY & 0.26 & 0.44 & $-0.434^{* *}$ & $-0.393^{* *}$ & $-0.280^{* *}$ & $0.637^{* *}$ & $0.259^{* *}$ & $-0.369^{* *}$ & $-0.282^{* *}$ & -0.013 & \\
10. IFURISE & 0.34 & 0.47 & $0.103^{*}$ & $0.136^{* *}$ & $0.113^{*}$ & -0.046 & 0.073 & -0.077 & $-0.094^{*}$ & 0.076 & 0.023 \\
\hline
\end{tabular}

$\mathrm{N}=455 ;{ }^{*}<<.05 ; * * \mathrm{p}<.01$ (2-tailed) 
Table 2 - ANOVA Results for Comparison (SPDummy 1 or 0)

\begin{tabular}{|c|c|c|c|c|c|c|c|}
\hline Variable & Means and SDs & $\mathbf{N}$ & Source of Variation & Sum of Squares & df & Mean Square & $\mathbf{F}$ \\
\hline FFR & $\begin{array}{l}0 \rightarrow 7.34(\mathrm{SD}=3.43) \\
1 \rightarrow 3.91(\mathrm{SD}=2.13)\end{array}$ & $\begin{array}{l}336 \\
119\end{array}$ & $\begin{array}{l}\text { Between Groups } \\
\text { Within Groups } \\
\text { Total }\end{array}$ & $\begin{array}{l}1036.218 \\
4476.881 \\
5513.099 \\
\end{array}$ & $\begin{array}{c}1 \\
453 \\
454 \\
\end{array}$ & $\begin{array}{c}1036.218 \\
9.883\end{array}$ & $104.851 * *$ \\
\hline PLR & $\begin{array}{l}0 \rightarrow 9.38(\mathrm{SD}=3.16) \\
1 \rightarrow 6.54(\mathrm{SD}=2.15)\end{array}$ & $\begin{array}{l}336 \\
119\end{array}$ & $\begin{array}{l}\text { Between Groups } \\
\text { Within Groups } \\
\text { Total }\end{array}$ & $\begin{array}{c}710.394 \\
3885.472 \\
4595.866 \\
\end{array}$ & $\begin{array}{c}1 \\
453 \\
454 \\
\end{array}$ & $\begin{array}{c}710.394 \\
8.577\end{array}$ & $82.824 * *$ \\
\hline DR & $\begin{array}{l}0 \rightarrow 6.38(\mathrm{SD}=2.72) \\
1 \rightarrow 4.67(\mathrm{SD}=2.16)\end{array}$ & $\begin{array}{l}336 \\
119\end{array}$ & $\begin{array}{l}\text { Between Groups } \\
\text { Within Groups } \\
\text { Total }\end{array}$ & $\begin{array}{c}258.348 \\
3032.013 \\
3290.361 \\
\end{array}$ & $\begin{array}{c}1 \\
453 \\
454 \\
\end{array}$ & $\begin{array}{c}258.348 \\
6.693\end{array}$ & $38.599 * *$ \\
\hline DRFFR & $\begin{array}{l}0 \rightarrow-0.96(\mathrm{SD}=1.04) \\
1 \rightarrow 0.76(\mathrm{SD}=0.38)\end{array}$ & $\begin{array}{l}336 \\
119\end{array}$ & $\begin{array}{l}\text { Between Groups } \\
\text { Within Groups } \\
\text { Total }\end{array}$ & $\begin{array}{l}259.762 \\
380.449 \\
640.211 \\
\end{array}$ & $\begin{array}{c}1 \\
453 \\
454 \\
\end{array}$ & $\begin{array}{c}259.762 \\
0.840\end{array}$ & $309.298 * *$ \\
\hline PLRFFR & $\begin{array}{l}0 \rightarrow 2.04(\mathrm{SD}=1.04) \\
1 \rightarrow 2.63(\mathrm{SD}=0.75)\end{array}$ & $\begin{array}{l}336 \\
119\end{array}$ & $\begin{array}{l}\text { Between Groups } \\
\text { Within Groups } \\
\text { Total }\end{array}$ & $\begin{array}{c}30.66 \\
425.75 \\
640.211 \\
\end{array}$ & $\begin{array}{c}1 \\
453 \\
454 \\
\end{array}$ & $\begin{array}{l}30.66 \\
0.940\end{array}$ & $32.622 * *$ \\
\hline USCAN & $\begin{array}{l}0 \rightarrow 1.27(\mathrm{SD}=0.16) \\
1 \rightarrow 1.13(\mathrm{SD}=0.13)\end{array}$ & $\begin{array}{l}336 \\
118\end{array}$ & $\begin{array}{l}\text { Between Groups } \\
\text { Within Groups } \\
\text { Total }\end{array}$ & $\begin{array}{c}1.723 \\
10.929 \\
12.652 \\
\end{array}$ & $\begin{array}{c}1 \\
453 \\
454 \\
\end{array}$ & $\begin{array}{l}1.723 \\
0.024\end{array}$ & $71.246^{* *}$ \\
\hline USUK & $\begin{array}{l}0 \rightarrow 0.59(\mathrm{SD}=0.09) \\
1 \rightarrow 0.53(\mathrm{SD}=0.07)\end{array}$ & $\begin{array}{l}336 \\
118\end{array}$ & $\begin{array}{l}\text { Between Groups } \\
\text { Within Groups } \\
\text { Total }\end{array}$ & $\begin{array}{l}0.337 \\
3.889 \\
4.226 \\
\end{array}$ & $\begin{array}{c}1 \\
453 \\
454 \\
\end{array}$ & $\begin{array}{l}0.337 \\
0.009\end{array}$ & $39.156^{* *}$ \\
\hline UNRATE & $\begin{array}{l}0 \rightarrow 6.16(\mathrm{SD}=1.39) \\
1 \rightarrow 6.11(\mathrm{SD}=1.36)\end{array}$ & $\begin{array}{l}336 \\
118\end{array}$ & $\begin{array}{l}\text { Between Groups } \\
\text { Within Groups } \\
\text { Total }\end{array}$ & $\begin{array}{c}0.227 \\
871.247 \\
871.474 \\
\end{array}$ & $\begin{array}{c}1 \\
453 \\
454 \\
\end{array}$ & $\begin{array}{l}0.227 \\
1.928\end{array}$ & 0.118 \\
\hline IFURISE & $\begin{array}{l}0 \rightarrow 0.34(\mathrm{SD}=0.47) \\
1 \rightarrow 0.36(\mathrm{SD}=0.48)\end{array}$ & $\begin{array}{l}336 \\
119\end{array}$ & $\begin{array}{l}\text { Between Groups } \\
\text { Within Groups } \\
\text { Total }\end{array}$ & $\begin{array}{c}0.055 \\
102.459 \\
102.514\end{array}$ & $\begin{array}{c}1 \\
453 \\
454 \\
\end{array}$ & $\begin{array}{l}0.055 \\
0.226\end{array}$ & 0.244 \\
\hline
\end{tabular}

$* \mathrm{p}<.05 ; * * \mathrm{p}<.01$

Logistic regression results in Table 3 show that there is statistically significant negative relationship between SPDummy and PLRFFR $(\beta=0.771$, at $\mathrm{p}<0.01)$. This means, the presence of positive spread between federal funds rate and discount rate is positively associated with larger spread between federal funds rate and prime loan rate. These results show strong support for Hypothesis 2.

Table 3 - Logistic Regression Results - Dependent Variable: SPDummy (Presence of Positive Spread)

\begin{tabular}{l|c}
\hline \multicolumn{1}{c}{ Variables } & Beta \\
\hline Intercept & $-3.189^{* *}$ \\
\hline PLRFFR & $0.771^{* *}$ \\
\hline UNRATE & 0.054 \\
\hline IFURISE & -0.038 \\
\hline Cox \& Snell R-SQ & 0.074 \\
\hline Wald Chi-Square & $34.810^{* *}$ \\
\hline Log Likelihood & 485.442 \\
\hline$* \mathrm{p}<.05 ; * * \mathrm{p}<.01$ &
\end{tabular}

Finally, Table 4 includes the results for Hypothesis 3 and 4 . Although prior to Prais-Winsten Transformation, the model is significant and some significance is observed between PLRFFR and USCAN and the dummy representing the rise in unemployment, that significance goes away after transformation. As autocorrelation is a major problem in time based data we have to consider the results with the appropriate transformation applied. According to these results there is no significance between PLRFFR and both of the exchange rate variables and unemployment variables so there is no support for Hypothesis 3 and 4. The implications for these and the above findings will be further discussed in the following section. 
Table 4 - Regression Results - Dependent Variable: PLRFFR

\begin{tabular}{l|c|c}
\hline \multicolumn{1}{c|}{ Variables } & Prior to Prais-Winsten Transformation & After Prais-Winsten Transformation \\
\hline CONSTANT & PLRFFR & PLRFFR \\
\hline USCAN & $-1.878^{* *}$ & 2.01 \\
\hline USUK & $2.757^{* *}$ & -454 \\
\hline UNRATE & 1.066 & 0.124 \\
\hline IFURISE & -0.006 & 0.115 \\
\hline Durbin-Watson & $0.242^{* *}$ & -0.007 \\
\hline Model F Statistic & 0.262 & 2.05 \\
\hline Model R & $41.85^{* *}$ & 0.48 \\
\hline
\end{tabular}

$* \mathrm{p}<.05 ; * * \mathrm{p}<.01$

\section{DISCUSSION}

The starting point of this study was to show the impact of FED's monetary policies on the value of dollar. The operationalization of FED's activism was done by looking at the spread between federal funds rate and discount rate. Hypothesis 1 predicted that the presence of positive spread to have negative effect on dollar's value. Our ANOVA results supported that contention. During the times of positive spread, which we consider to be the time FED discouraging the banks to use its funds and rather borrowing from each other, the value of dollar was significantly low comparing to the times where FED actively encouraged banks to borrow directly from FED. We believe this is an indication of FED's monetary policies' effect. In short, when FED is actively pursuing to impact the market players through its main tool, monetary policy, the international players consider that to have positive impact on the value of dollar. Furthermore, our results show that, the spread between federal funds rate and discount rate also impacts the spread between federal funds and prime loan rate. Sweeney (2007) mention the systematic risk associated with dollar according to FED's policies. Lobo (2000) talks about the assymetric effects of interest rates on stock market performance. In short, FED's monetary policy is a main determinant of market variables. Once FED cuts the sources to banks, they react by increasing their risk premium through increasing the difference between their cost of borrowing and the cost of capital they charge to businesses. This chain reaction effect makes intuitive sense. In his classical work, Keynes (1936) talks about the negative relationship between interest rates and investment activities of the business. Considering his classical assumption, higher interest rates charged by banks to businesses should decrease their level of investment thus raise unemployement. Hypothesis 3 and 4 predicted this connection. In Hypothesis 3, the difference between federal funds rate and the prime rate considered to have negative effect on the value of dollar due to decrease in investment activities. Hypothesis 4 was about the connection to unemployment. Our results did not show support for these connections. We believe there are some important implications of this lack of connection. First of all, FED's actions do impact banks' actions but banks' actions do not mean a lot in determening the value of the dollar. This means, the international players of currency closely look at FED's monetary policies but not the banks' risk premium chargings. In other words, FED is the key player, if not the only player, in determining value of the American dollar. Furthermore, our data do not show support for the unemployement connection. We believe, several other variables are to be considered for analysis of unemployment and its determinants. The lack of support for Hypothesis 4 does not mean refuting the classical assumptions of Keynes (1936) and should only be considered within the context of this study. Testing the classical assumptions was beyond the scope of this study and needs more comprehensive datasets, not to mention more advanced quantitative methods.

\section{CONCLUSION}

Recent economic crises in different parts of the world have showed us that both fiscal and monetary policies of United States have direct effect on rest of the planet. In some of the developing countries there is a saying; "When U.S. sneezes, the rest of the world coughs!" FED, being the independent player of monetary policies of America, thus the governing body of American Dollar, is seen as the source of negative or positive signals for the value of dollar. Our results showed that, FED's macroeconomic actions correlate with the international value of American Dollar. Furthermore, those actions impact the actions of domestic banks. However, the reaction does not spill to investment or unemployment. Considering U.S. Dollar to be major currency of the global economy, FED is 
one of the key actors in this game. Final word is "World is looking towards FED when building the perception about the value of the dollar."

\section{AUTHOR INFORMATION}

Matthew Nga Uwakonye was an Interim Dean in the College of Business at Grambling State University, Grambling Louisiana. Dr. Matthew Uwakonye teaches Economics and Business Statistics at an Undergraduate and graduate levels. He has authored and co-authored several articles in refereed journals and conference proceedings in various areas of economics, Agricultural economics, and Business Administration. He is Larry Lundy Endowed Professor of economics in the College of Business at Grambling State University. E-mail: m_uwakonye@yahoo.com. Corresponding author.

Guclu Atinc, Louisiana Tech University. E-mail: atincm@gram.edu

Yasmine Ocal Atinc, Grambling State University.

\section{REFERENCES}

1. Atesoglu, S. (2003). Monetary transmission-federal funds rate and prime rate. Journal of Post Keynesian Economics, 26 (2), 357-364.

2. Broaddus, A., \& Cook, T. (1983). The Relationship Between the Discount Rate and the Federal Funds Rate Under the Federal Reserve's Post October 6, 1979 Operating Procedure. Economic Review , 69 (1), 12-16.

3. Cook, T., \& Hahn, T. (1989). The effect of changes in the federal funds rate target on market interest rates in the 1970's. Journal of Monetary Economics , 24, 331-351.

4. Cook, T., \& Hahn, T. (1988). The information content of discount rate announcements and their effect on market interest rates. Journal of Money, Credit, and Banking , 20, 167-180.

5. FRB: Monetary Policy. (2009, Feb.). Retrieved Feb. 10, 2009, from Federal Reserve System Web Site: http://www.federalreserve.gov/monetarypolicy/discountrate.htm

6. Jensen, G. R., Mercer, J. M., \& Johnson, R. (1996). Business Conditions, Monetary Policy, and Expected Security Returns. Journal of Financial Economics , 40, 213-237.

7. Keynes, J. (1936). The General Theory of Employement, Interest, and Money. New York: Harcourt Brace.

8. Lobo, B. J. (2000). Assymetric Effects of Interest Rate Changes on Stock Prices. The Financial Review , 35 (3), 125-143.

9. Madura, J., \& Schnusenberg, O. (1998). Federal Reserve Policy and Information Flow. Managerial Finance, 24 (8), 3-15.

10. Miller, R. L., \& VanHoose, D. (2004). Macroeconomics-Theories, Policies and International Applications (3rd Edition ed.). South-Western.

11. Seiler, M. J., Shyu, P., \& Sharma, J. (1998). Do changes in the Discount Rate and Fed Funds Rate Affect Financial Market Returns? Managerial Finance , 24 (8), 16-25.

12. St.Louis Fed: Employement \& Population: Download Data. (2009, Feb). Retrieved Feb 12, 2009, from Federal Reserve System-St.Louis Web Page: http://research.stlouisfed.org/fred2/categories/10/downloaddata

13. Sweeney, R. (2007). Fed intervention, dollar appreciation, and systematic risk. Journal of International Money and Finance , 26 (2), 167-.

14. Thorbecke, W. (1997, June). On Stock Market Returns and Monetary Policy. Journal of Finance, 635-654.

15. Thorton, D. L. (1994). Why do T-Bill Rates React to Discount Rate Changes? Journal of Money, Credit, and Banking , 26 (4), 839-849.

16. Waud, R. (1970, March). Public Interpretation of Federal Reserve Discount Rate Chanes: Evidence on the "Announcement Effect.". Econometrica , 231-250. 


\section{NOTES}

